\title{
対人感情と対人行動と情緒の関連 ${ }^{1}$
}

立正大学齊藤勇 ${ }^{2}$

Interpersonal sentiments, social behaviors and emotions

Isamu Saito (Department of Psychology, Faculty of Liberal Arts,

Rissho University, Shinagawa-ku, Tokyo 141)

Sixty individuals (30 male/30 female) served as subjects in an experiment designed to investigate a person's felt emotions while engaged in social interactions with other people. The social interaction situations explored here represented various combinations of the following three variables: (1) eight kinds of sentiments about the other person; (2) eight kinds of social behavior directed to the other person; (3) sex of the other person. Subjects' responses to questioning revealed that a person's emotional reaction is heavily dependent upon the interpersonal sentiments pertaining in a given situation. Very different emotional reactions were associated with differences in interpersonal sentiments even when the pattern of social behavior remained constant. It was also found that emotional reactions changed when different patterns of social behavior were employed with a given individual.

Key words: interpersonal sentiments, emotions, liking, dislike, soical interactions, interpersonal behaviors, attraction.

人が他者を相互作用する場合，初対面等特別の場合を 除いては相手の人に，たと光ば好意とか嫌悪といった感 情傾向をむっている. 人はこの対人感情をべースに相手 の人との相互作用を行っている. この対人間の相互作用 は, 互いに相手の人から行動をらけ，また相手の人に行 動を行らといら2 人の間の行動のやりとりである.この ような行動の交換は各々の個人内に招いて相手の行動の 認知, 評価, そこから生じる情緒, 相手への欲求などの 心理的プロセスを生じる。対人関係の研究はこの対人行 動と心理のプロセスを究明することにある。ここでは相 手の人への感情傾向を基礎に, 相手の人への行動とその 時感じる情緒との関連をみていくことにする.

対人間の相互作用に括将る情緒の生起について検討す ると，2つの生起状況が考光られる．まず相手の人から ある行動を受けたとき，人はなんらかの情緒を感じるで あるら、また自分が相手の人にある行動をするときな んらかの情緒をもって行らであらう。このように本稿で は対人間の行動を, 相手からある対人行動を受ける場合 と，相手に対してある対人行動を行ら場合の 2 つ過程 汇分けて考兄，各過程と情緒との関連を検討している. ところで前者の相手からある対人行動を受けた場合の情 緒については既に齊藤（1985）によって検討されてい る. 本論文は後者, つまり相互作用に揖いて相手にある

1 本研究の一部は日本心理学会第 49 回大会に打いて 発表した。

2 本論文の作成にあたり小林美恵子氏 (立正大学) に 甚大な御協力を載いた。 氏に心から感謝します。
対人行動を行う場合，人が感じる情緒について実証的デ 一夕を集収し検討していくことを目的とする。本研究の 基本的考兄方は齊藤（1985） 亿示して市るよう飞 McDougall (1908), Heider (1958), Arnold (1960), Schachter (1964)，そ机に Kemper (1978）らの考光に基づ いている.

\section{方 法}

質問紙調查法により上記目的の実証的データを得るた ぬ, 以下のような質問紙調查表を作成し，調査を実施し た. 調查表作成過程については齊藤 (1985) 飞記載して ある.

1. 調查表 作成した質問紙調查表は次の通りであ る.

a）設問：調查表の設問は次の通りである.“ある人 が 1-8 の上うに思っている同性あるいは異性の相手 の人に以下の上らな行動をするとき，その人はらつうど のような感情や情緒をもちながらその行動索行い, 枽た その行動が終った後でどのような感情をもらやすいか。 各感情について，そのような感情をもつ場合‥○、もた ない場合‥】を各欄に記入し，全マス目をらめて下さ い”ここでの 1-8 とは対人感情項目である.

b) 対人感情項目: 対人感情項目は次の 8 項目であ る. 調查表の 8 つの対人感情項目欄には（）内の上う な説明が書かれている.

1. 好意の感情傾向（好意をもっている人）

2. 慈愛の感情傾向（かわいい，いじらしいと思ってい る人) 
3. 優越の感情傾向（自分の方が優位・相手が下の人）

4. 軽蔵の感情傾向（茂視, 見下げている人）

5. 嫌悪の感情傾向（嫌悪感をもっている人）

6. 恐怖の感情傾向（恐ろしいと思っている人）

7. 劣等の感情傾向 (自分の方が劣位・相手が上の人)

8. 尊敬の感情傾向（尊敬している人）

c) 対人行動項目: 対人行動項目は次の 8 項目であ る.

1. 友好的行動，2. 依存的行動，3. 服従的行動，4. 回 避的行動, 5. 拒否的行動, 6. 攻撃的行動, 7. 支配的行 動, 8. 援助的行動.

d）情緒項目：情緒項目は臍藤（1985）と同一の 38 項目である。

e ） 行動の前後項目：上記の対人行動を行うときと その行動を終えた後の感情を各及別個に調べるために, 回答欄の各対人行動項目の下に, 対人行動を行うとを之 終った後の $2 つ の$ 欄が設けられている.

f）性別項目：対人行動を行うとき，相手の性別飞よ り感じる情緒は異なると考兄られる。このため各回答欄 は相手の人の性別として, 同性の場合と異性の場合の 2 つの闌が設定されている.

2. 調査の手続きとデー夕の整理 a) 被験者: 大学 生 60 名 (男子 30 名, 女子 30 名).

b) 調查手続き: 1983 年 12 月, 教室に拁いて調查表 を配布し, 時間内（1時間）飞回答を終えた者はその場 で回収し, 回答し終えない者は 1 週間後に回収した.

c) データの整理：マトリックスは対人感情項目 8, 対人行動項目 8 , 行動の前後項目 2 , 情緒項目 38 , 性別項目 2 で, $8 \times 8 \times 2 \times 38 \times 2$ となり, 全セル数は 9728 である. 各セルの回答を被調査者の男・女別住 】の数を数光, 19456 の比率を算出した. これが基礎デ ータである.ここでは紙面の関係上，対人感情のなかで も最も重要な感情傾向である好意の感情傾向之嫌悪の感 情傾向の 2 項目について相手に対人行動を行らとさの対 人行動之情緒の関連についてみていくことにする.

d) 結果の表現: “結果と考察”に扔ける各状況での “情緹を感じる”之回答した人の比率の表現は就拉よそ 次の基準に従っている.“汪とんどの人は…である”と いう表現は各セルの生起比率の差の検定に和いて, 1\% レベルで有意の $76.67 \%$ 以上の場合である $\left(X^{2}=8.533\right.$, $d f=1$ ). “多くの人は…である” $50 \%$ 以上の場合, “...の人も少なくない”は 35-49\% の場合である.

\section{結果と考察}

\section{1. 対人行動別にみを情緹の生起}

対人場面飞执いて相手の人に㐫る行動を行う場合，人 はどのような情緒をもつであろうか，対人相互作用場面 で感じると思われる情緒について, 上記の調査結果をも とに，その人にもっている好意と嫌悪の感情傾向別，対
人行動別に整理した. これをむとに対人関係に批いて, 相手にある一定の対人行動を行うとき, 人が感じる情緹 を順次みていくことにする. 対人感情と対人行動との関 係から生起する主要情緒 (Ekman, 1982) については Table 1 に示してある.

（1）友好的行動を行う之きの情緹：好意をむってい る人に友好的行動を行う場合, ほと几どの人が好感な じみ，喜び，られしさを感じている，また男女子も異性 に友好的行動を行う場合, 愛情を感じる人が多い, 男子 は女子に友好的行動を行うとき，その相手の人をかわい いと思う気持（男女間 $\chi^{2}=14.70, d f=1, p<.01$ ) 之自 らが䎵ずかしいといら気持（男女間 $\chi^{2}=4.59, d f=1$, $p<.05)$ をるちやすい，逆に女子が男子に文好的行動 を行うときは甘学感じている人が多い（男女間 $\chi^{2}=$ 4. 44, $d f=1, p<.05)$.

一方，嫌いな人に友好的行動を行う場合，男女子も多 くの人が嫌悪感やイライラ, 村むたさ, 不満などを感じ ている.

（2）依存的行動を行うときの情緒：好意をもってい る人に依存的行動起行うとき, 男女とも多くの人が感謝, 好感,なじみ，気安さなどを感じている，また異性の人 飞依存的行動をするときは男女とも愛情を感じている人 が多い。また女子が依存的行動をするとさは男子より も安心感を感じている人が多い $\left(\chi^{2}=4.59, d f=1, p<\right.$ .05). 男子が女子に依存的行動を行うときは恥ずかしさ を感じている人が少なくない，男女とも異性に依存的行 動をするときは同性に比べて甘学感じることが多い。

一方, 嫌いな人に依存的行動を行らときは, 多くの人 が屈辱感やくやしさ，嫌悪感を感じている.

（3）服從的行動を行らときの情緒：服從的行動を行 うときは，明確な性差が方られ，男女に上り，また相手 の人の性別により感じる情緒がかなり巽なっている. 男 子は相手に好意をもっている場合でも, 服従的行動を行 うときは屈辱感をもち（男女間 $\chi^{2}=6.24, d f=1, \quad p<$ .02), 不満を感じている（男女間 $\chi^{2}=7.94, d f=1$, $p<.01)$ 人が少なくない。この結果から, 男子は服從的 行動を行う場合，大きな心理的抵抗や負担を感じている ことが分かる，逆に女子は好意をもっている人に服從的 行動を行うときは多くの人が敬意を感じ，特に相手が男 性の之き忷好感や愛情（男女間 $\chi^{2}=5.45, d f=1, \quad p<$ .02）を感じながら行う人が多い，女子の場合，好意を もっている人に対する服従的行動はポジティブな行動々 考壳ることができる.

一方，嫌いな人に服従的行動を行う場合，ほとんどの 人が嫌悪感や屈辱感を感じている．䎬いな人に対する情 緒には性差は少ないが，男子の半数が劣等感を感じてい る点が目につく(男女間 $\chi^{2}=4.59, d f=1, p<.05$ ).

（4）回避的行動を行うときの情緒：好意をるってい 


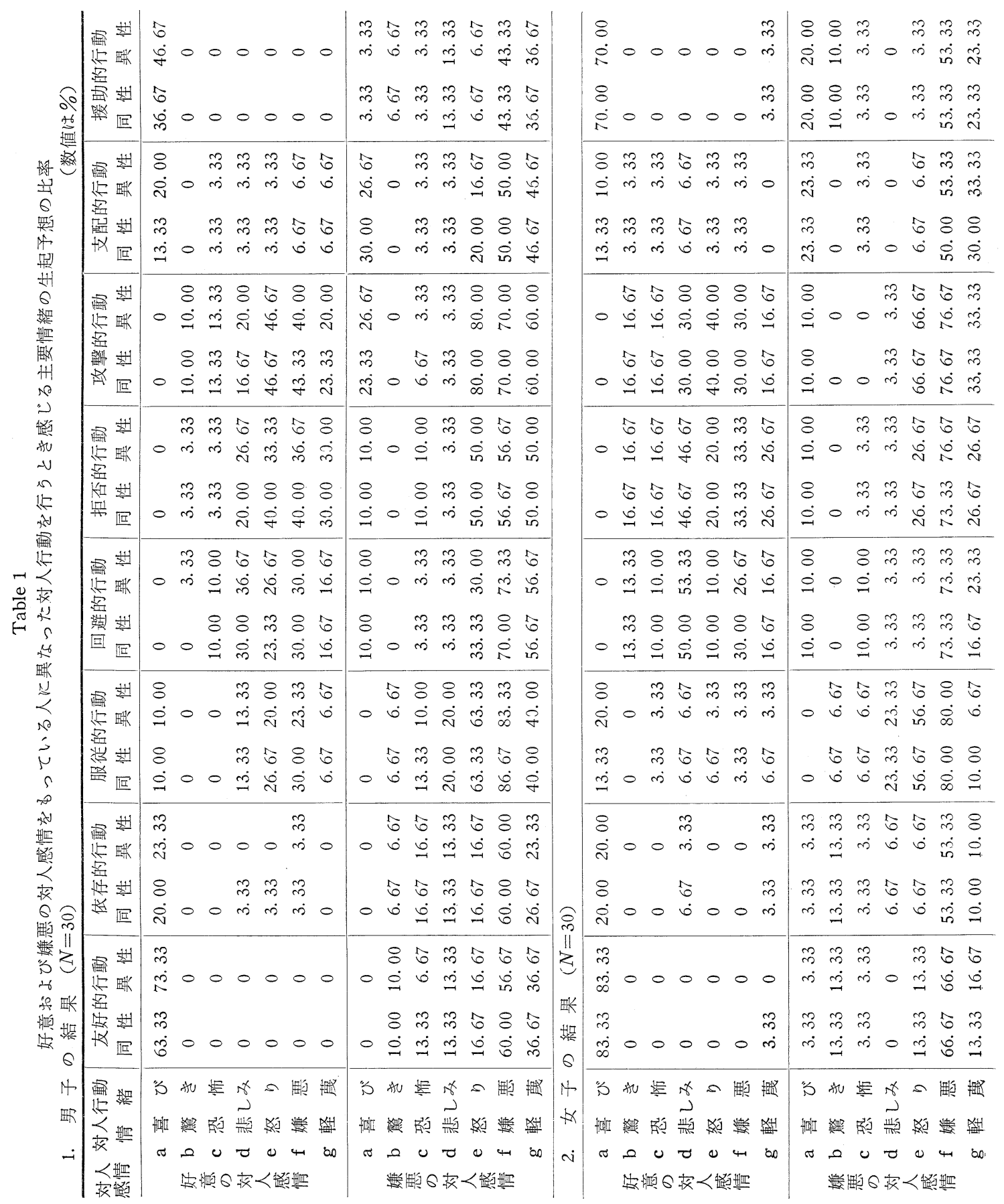

る人に対して回避的行動を行う場合, 多くの人が気がね やさびしさを感じ, 悲しみや不安, 苦しみを感じる人も 少なくない。

一方, 嫌いな人に回避的行動を行ら場合は, 多くの人

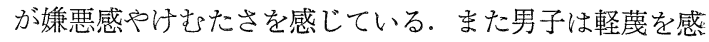
じた場合, 回避的行動をとるという人も少なくない（男 女間 $\left.\chi^{2}=10.33, d f=1, p<.01\right)$.

（5）拒否的行動を行うときの情緒：好意をもってい 
る人に拒否的行動を行うとき感じる情緒は, 回避的行動 を行うとさと核涪同様の傾向を示している。 また女子は 男子に比べて拒否的行動を行うことに不安が伴っている. 一方，嫌いな人に拒否的な行動を行うときは，多くの 人が嫌悪感を感じている。また軽䨖感, 憎悪感, 怒りな ぞの情緒をるつ人が少なくない。

（6）攻撃的行動を行うときの情緒：好意をもってい る人に攻撃的行動を行うのは, イライラ感じたり, 不安, 怒りの気持をるったときである。

一方，嫌いな人に攻撃的行動を行うときは，汪とんど の人が怒りを感じ，多くの人が嫌悪感と憎悪感を感じて いる。 また多くの男子は軽茂感をもっている（男女間 $\left.\chi^{2}=4.29, d f=1, \quad p<.05\right)$.

（7）支配的行動を行うときの情緒：好意をもってい る人に支配的行動を行うときは好感や優越感をもつ人が 少なくない，また気がねを感じる人るいる，男子は女子 に支配的行動を行うとさ, 愛情やかわいらしさ（男女間 $\left.\chi^{2}=6.94, d f=1, p<.01\right)$ を感じている.

一方, 嫌いな人に支配的行動を行うときは優越感, 嫌 悪感を感じている人が少なくない. 男子の場合, 軽蒇感 をもっている人も少なくない。

（8）援助的行動を行うときの情緹：好意をもってい る人に援助的行動を行うとき, ほとんどの人が好感を感 じ，多くの人が喜びやなじみ，られしさを感じる，また 優越感や気安さを感じる人も少なくない. 性別では男子 は好きな女子に対して援助的行動を行うときに, 愛情や かわいらしさを感じることが多く，女子は相手の性別に かかわりなく愛情やかわいらしさを感じる.

一方，嫌いな人に援助的行動を行うとき，優越感をも つ人もいるが，嫌悪感や特に女子はイライラや不満をも ちながら援助的行動をしている人が少なくない。

2. 結果の概括

対人感情と対人行動との関連から, 情緒生起飞ついて 大枠を知るために，ここで，各々をポジティブとネガテ ィブに大別して，調查結果をまとめてみることにする.

対人感情については, 本稿では好悪の感情傾向のみを 分析したので，相手に対する好意の感情傾向をポジティ ブな感情傾向, 嫌悪の感情傾向をネガティブな感情傾向 とする.

対人行動については, 相手に行ら対人行動を分析して Wるので, 援助的行動, 友好的行動, 依存的行動, 支配 的行動をポジティブな行動とし, 回避的行動, 拒否的行 動，攻撃的行動をネガティブな行動とする.

情緒については, 齊藤（1985）と同一である.

このような大枠の分類により，上記結果を概括する
と次のようになる.

（1）ポジティブな対人感情をもっている人に，ポジ ティブな行動を行う場合, 人は好感等ポジティブな情緒 を感じやすい。

（2）ポジティブな対人感情をるっている人に，ネガ ティブな行動を行う場合，人は寂しさや悲しみ，また不 安のような内に向からネガティブな情緒を感じやすい.

（3）ネガティブな対人感情をもっている人に，ポジ ティブな行動を行う場合, 人は嫌悪感等ネガティブな情 緒を感じやすい。

（4）ネガティブな対人感情をるっている人に，ネガ ティブな行動を行う場合, 人は嫌覀感, 怒り, 軽藿感な ぞ外に向からネガティブな情緒を感じやすい。

対人感情と情緒之対人行動の関連は以上の上うに要約 される.しかし，これはめくまで概略で，正確には結果 と考察の 1. で分析したように, 対人場面において感じ る情緒は各状況状況により異なり, 数個にグルーピング することはむしろ難かしいとい方よう. 各対人感情と各 状況により異なった情緒が感じられるのである. 当然の ことであるが，それが人の感じる情緒の複雑さであり， 豊富さである，それ故，Kemper (1978) や齊藤 (1985) の論及の如く, 対人感情や情緒の社会心理学的研究は, 状況との関連を詳細に検討していくといらアプローチが 重要であるといえ，ここでの結果の多様性はその考光を 支持しているといえよう.

\section{引用文献}

Arnold, M. B. 1960 Emotion and personality. New York: Columbia University Press.

Ekman, P. (Ed.) 1982 Emotion in the human face. New York: Cambridge University Press.

Heider, F. 1958 The psychology of interpersonal relations. New York: John Wiley \& Sons.

Kemper, T. D. 1978 A social interactional theory of emotions. New York: John Wiley \& Sons. McDougall, W. 1908 Introduction to social psychology. London: Methuen.

齊藤 勇 1985 対人感情之情緒の人間関係的アプロー 于 心理学研究, 56, 222-228.

Schachter, S. 1964 The interaction of cognitive and psychological determinants of emotional state. In L. Berkowitz (Ed.), Advances in experimental social psychology. Vol.1. New York: Academic Press. Pp. 49-80.

- 1985.7.31. 受稿, 1986.5.10. 受理— 